\title{
Interannual variability in dry and wet spell characteristics over Zambia
}

\author{
S. Hachigonta, C. J. C. Reason* \\ Dept. of Oceanography, University of Cape Town, Rondebosch, 7701, South Africa
}

\begin{abstract}
We studied the variability of dry and wet spell frequency over Zambia during the core of the rainy season (December to February, DJF), and associated circulation anomalies. Zambia's large rural population depends critically on rain-fed agriculture; in general, the southern part of Zambia is prone to a high number of dry spells during DJF, and to wet spells of short duration, while the northern regions of the country more typically have a large number of wet spells during DJF, which can lead to flooding. Good rainfall over southern Zambia is typically associated with low level convergence of moisture emanating from the tropical southeast Atlantic Ocean and the tropical western Indian Ocean. During seasons with increased numbers of dry spells over Zambia, low level easterly anomalies typically exist over Zambia, thereby reducing moisture from the tropical southeast Atlantic. Seasons with reduced dry spell frequency and more wet spells tend to be characterised by low level westerly anomalies over southern Angola and western Zambia. Furthermore, DJF seasons occurring during the mature phase of El Niño (La Niña) events tend to show above (below) average dry spell frequency. All El Niño seasons during the period of study showed reduced frequency of wet spells over Zambia, but not all La Niña events were associated with above average wet spell frequency. In fact, wet spell frequency over Zambia during several neutral seasons was greater than that observed during some La Niña events. A relatively strong relationship between anomalies in dry spell frequency and Niño 3.4 sea surface temperature (SST) was found. Relationships with Indian Ocean SST anomalies were also explored, but these were weaker than those found for Niño 3.4 SST.
\end{abstract}

KEY WORDS: Dry spell frequency · Zambia $\cdot$ ENSO $\cdot$ Interannual variability

\section{INTRODUCTION}

Rainfall in Zambia is highly irregular in space and time, which makes cultivation of crops such as maize difficult. Small differences in the amounts and timing of rain at a particular site may determine the success or failure of critical stages in maize production, which is the nation's staple food. With a relatively large and impoverished rural population that largely relies on rain-fed agriculture, Zambia is vulnerable to the impacts of rainfall variability, posing challenges for food security and planning (Vogel \& O'Brien 2003).

Research into rainfall variability has tended to consider anomalies in seasonal totals as the focus for study. Similarly, seasonal forecasts often predict rainfall over large regions - i.e. whether the rainfall for the forth- coming season will be below, near, or above average (e.g. Vogel \& O'Brien 2003, Johnston et al. 2004). However, as emphasized at regional climate meetings (such as the Southern African Regional Outlook Forum, SARCOF, run by the Drought Monitoring Centre for southern Africa), more specific information is required by operational meteorologists and decision makers (e.g. farming, health and water-resource managers) on the likely onset and end dates of rainy seasons, as well as on the number and intensity of dry and wet spells within it. For example, a good crop yield is more likely with uniformly spread light rains than with a few spells of heavy rains interrupted by dry periods (Usman \& Reason 2004). At SARCOF meetings, consensus forecasts (in terms of the probability of above, below, or near average rainfall totals) for the early and late sum- 
mer rainy seasons over each southern African country (such as Zambia) are issued based on the outputs from SST(sea surface temperature)-regional rainfall regression models and General Circulation Model (GCM) products obtained from the South African Weather Service, the UK Meteorological Office, the European Centre for Medium-Range Weather Forecasts and the International Research Institute. However, the need by user groups for information about onset dates and dry/wet spells needs to be specifically addressed, particularly for regions depending on predominantly rain-fed subsistence agriculture such as Zambia. Thus, Zambia and the southern African region urgently need more tailor-made applications-oriented seasonal forecasts (e.g. Klopper 1999, Johnston et al. 2004).

However, improved forecasting relies on better understanding of the climate variability of the region and on assessing what rainy season characteristics might have some predictability. Possible relationships between large-scale climate modes or identifiable regional circulation anomalies and dry and wet spell characteristics need to be investigated. Furthermore, better understanding of how rainfall is distributed in terms of dry and wet spells through the core months of the summer rains (December-February, DJF), and the various circulation anomalies responsible for this variability, could help to improve long range forecasts over Zambia, thus helping agricultural extension officers provide advice to subsistence farmers.

Rainy seasons that have unusually high numbers of dry spells have helped cause economic, social, and environmental problems over many parts of Africa. In years with anomalously high number of dry spells during the rainy season, crop production is typically very poor. On the other hand, too many-or too intensewet spells quite frequently lead to flood-induced crop failure (e.g. Reason et al. 2005). In a study over East Africa, Stewart (1988) found that dry spell-induced crop shortages occurred once or twice every 5 yr. Previous work on wet and dry spells in southern Africa has examined their characteristics for Zimbabwe (Matarira \& Jury 1992), and the interannual variability in summer dry spell frequency over southern Africa as a whole (Usman \& Reason 2004) and over the Limpopo region of northern South Africa (Reason et al. 2005). However, very little research has been done on the variability of rainfall during the rainy season over Zambia. Therefore, one of the objectives of this paper is to investigate wet and dry spell characteristics over Zambia and to identify global and regional climatic features that influence the frequency of these dry and wet spells. Although summer rainfall totals are typically below (above) average over much of southern Africa during El Niño (La Niña) (Allan et al. 1996, Reason et al. 2000), it is not known how the El Niño Southern Oscillation
(ENSO) affects the characteristics of dry and wet spells that make up the summer rainy season over Zambia.

During the summer rainy season, the Inter-tropical Convergence Zone (ITCZ) migrates southwards to lie meridionally over the northern and eastern parts of Zambia with another convergence zone extending west across the country and into the heat low (Angola Low) that exists in the summer half of the year over SE Angola and NE Namibia. The Angola Low facilitates low level moisture influx from the tropical SE Atlantic (Cook et al. 2004) and if this moisture is able to significantly penetrate into Zambia and then converge with moisture emanating from the tropical western Indian Ocean, good rains are expected. East of Zambia, the ITCZ typically lies more or less zonally across northern Mozambique before exiting southern Africa out across the western Indian Ocean. At upper levels, the tropical easterly jet dominates the circulation over low latitude Africa and the subtropical westerly jet dominates south of $\sim 30^{\circ} \mathrm{S}$. Associated with this ITCZ distribution, the DJF moisture flux climatology over southern Africa (Fig. 1) is characterized at low levels by a NE monsoonal flow from the NW Indian Ocean, a SE flow over Zimbabwe and southern Mozambique from the SW Indian Ocean and a cyclonic flow over southern Angola and northern Namibia (the Angola Low) emanating from the tropical SE Atlantic. These 3 low level moisture inflows tend to converge over central Zambia and contribute to summer rainfall over the country. They are noticeably weaker in December than in January or February and this helps explain why there is a significant increase in average Zambian rainfall from December to January. The moisture inflows, and hence Zambian rainfall, are affected by ENSO and also by Indian Ocean and South Atlantic SST and circulation anomalies (e.g. Behera \& Yamagata 2001, Reason 2002, Rouault et al. 2003).

A better understanding of the variability of Zambian summer rainfall is needed, and thus a further objective of this study was to investigate the spatial-temporal patterns of dry and wet spell occurrence. Potential relationships between anomalies in dry and wet spell frequencies and anomalies in Niño 3.4 SST and in Indian Ocean SST are also considered to assess the predictability of rainy season rainfall based on the state of ENSO. A final objective was to better understand the circulation anomalies responsible for anomalous numbers of dry/wet spells during the rainy season.

\section{DATA AND METHODOLOGY}

The analysis of dry and wet spells focused on the DJF period (i.e. the core of the summer rainy season), as these months are critical for maize cultivation and 


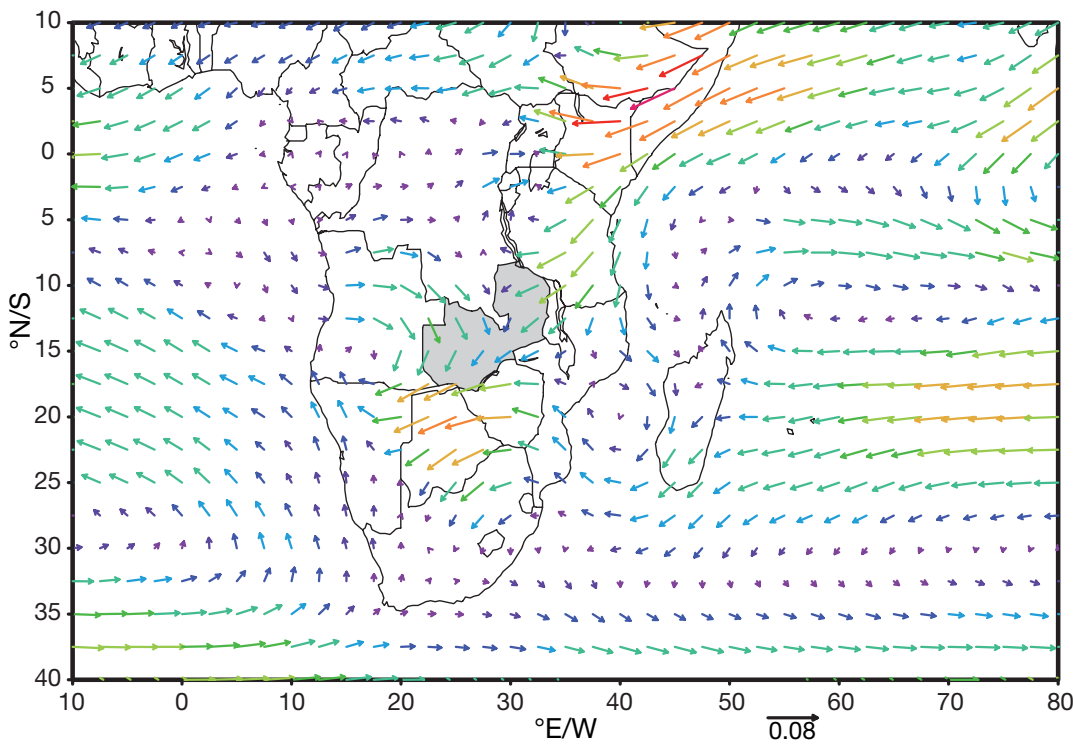

Fig. 1. Mean moisture flux at $850 \mathrm{hPa}$ over southern Africa for December to February (DJF), 1979-2000. Arrow below panel: scale vector $\left(\mathrm{kg} \mathrm{kg}^{-1} \mathrm{~m} \mathrm{~s}^{-1}\right)$. Zambia shaded grey

also usually correspond to the time of maximum rainfall. In the present study, a dry spell (following Usman $\&$ Reason 2004) was defined as a pentad (5 d) which receives $<5 \mathrm{~mm}$ rainfall, and a wet spell as a pentad receiving $>20 \mathrm{~mm}$ rainfall. Note that the Famine Early Warning System uses a similar dry spell definition ( $<4.25 \mathrm{~mm}$ per pentad; Usman \& Reason 2004). Consecutive dry pentads were counted as a single dry spell, and thus the duration of dry spells was variable.

Two rainfall data sets were used for the analysis of dry and wet spells over Zambia: (1) The Climate Prediction Center (CPC) Merged Analysis of Precipitation (CMAP) mean pentad rainfall data (Xie \& Arkin 1997), updated to July 2002. The CMAP rainfall data are precipitation estimates obtained from the merging of observations from rain gauges and rainfall estimates from satellite, and are produced on a global grid with a horizontal resolution of $2.5 \times 2.5^{\circ}$. The CMAP data set used here extends over 1979 to 2002, and has been used in recent southern African studies (e.g. Usman \& Reason 2004, Reason et al. 2005, Tadross et al. 2005). (2) Daily rainfall station data obtained from the Zambian Meteorological Department (see Fig. 2 for station locations). Station data was used in this study in order to demonstrate the robustness of the results where the 2 datasets agreed, or to caution against drawing firm conclusions where the datasets differed. These data were derived from 28 daily weather stations over the Zambia and cover 1979-2000 period.

A time series of area-averaged dry and wet spells over the region was created from the gridded
CMAP and station data sets and used to assess the dry and wet spell variability. On the basis of the dry spell time series, seasons with anomalously high frequencies of dry spells and wet spells were identified for further study, and the series as a whole further analysed by relating them to the Niño 3.4 time series index and to Indian Ocean SST.

To assess regional circulation anomalies associated with seasons of wellabove average numbers of dry or wet spells, NCEP-NCAR reanalyses (Kalnay et al. 1996) were used. Some of the anomalies in re-analysis parameters were plotted directly from the CDC website (www.cdc.noaa.gov/ HistData). Moisture transport over southern Africa and the adjacent oceans was calculated from the NCEP reanalysis data as the product of specific humidity $(q)$ and winds $(u, v)$, giving a vector $(q u, q v)$ for 8 pressure levels from $1000 \mathrm{hPa}$ to $300 \mathrm{hPa}$. In this study, the $850 \mathrm{hPa}$ and $350 \mathrm{hPa}$ level data were used to analyse the low and upper level moisture fluxes during seasons of anomalous number of wet and dry spells. Anomaly plots were calculated using a 20 yr monthly climatology (1979-1999), since the NCEP data are less reliable before 1979 due to a paucity of observations over the

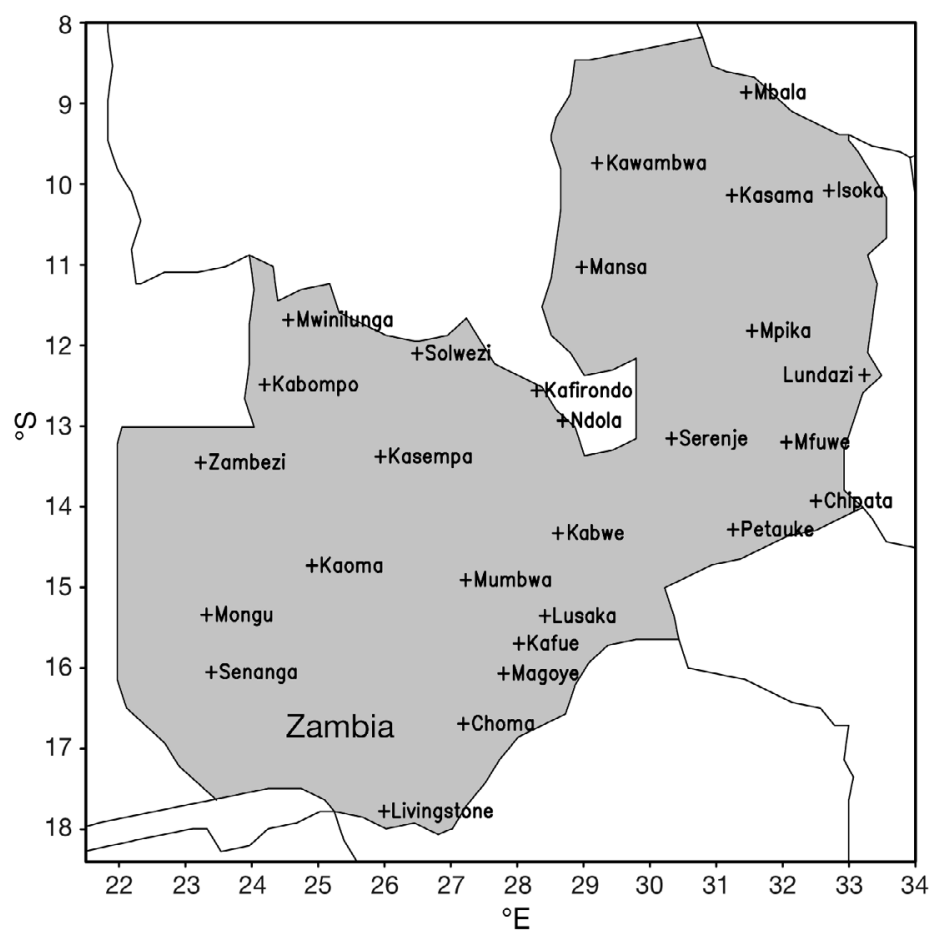

Fig. 2. Location of rainfall stations in Zambia 


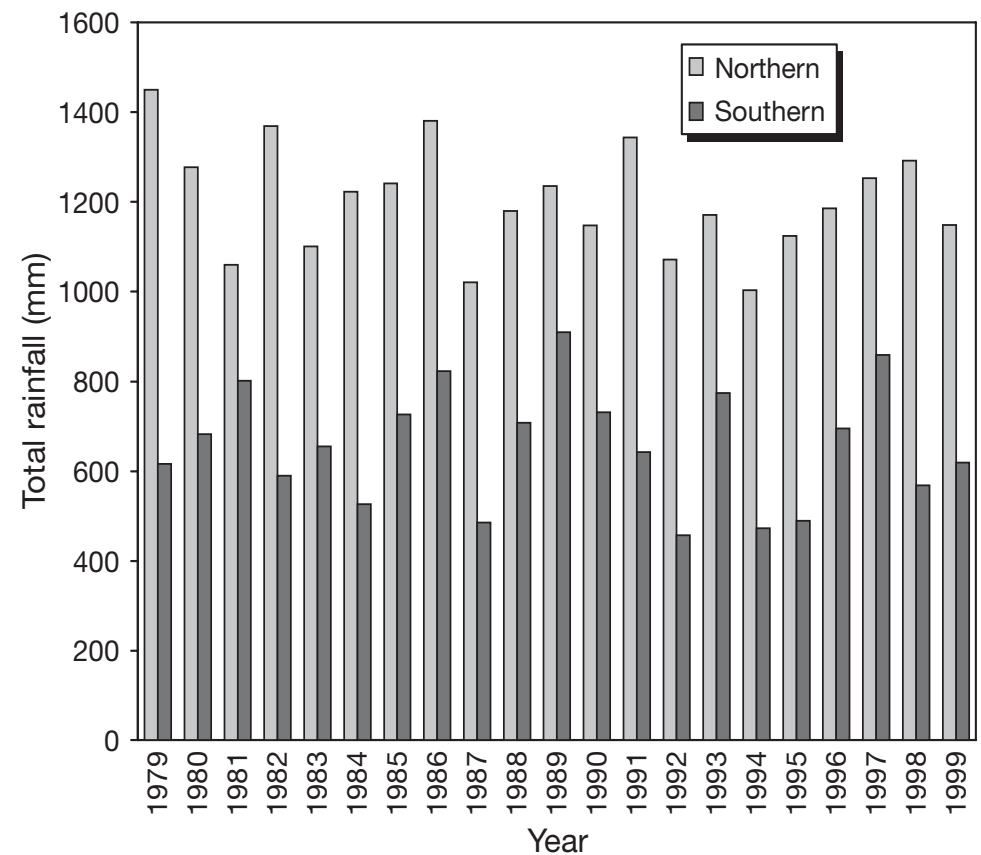

Fig. 3. Time series of station rainfall data in the northern (8 to $\left.15^{\circ} \mathrm{S}\right)$ and southern (15 to $18^{\circ} \mathrm{S}$ ) parts of Zambia for 1979-1999

Southern Hemisphere (Kalnay et al. 1996). Composites of SST and atmospheric circulation anomalies were constructed for seasons showing anomalously high dry/wet spell frequency.

\section{DRY SPELL CHARACTERISTICS}

Fig. 3 shows a comparison of annual rainfall totals between northern and southern Zambia for 1979 to 1999, derived from station rainfall data. For every year during the period, the northern part of Zambia (8 to $15^{\circ} \mathrm{S}$ ) received more rainfall than the southern region (15 to $18^{\circ} \mathrm{S}$ ) and generally displayed less interannual variability. The mean $\pm \mathrm{SD}$ rainfall for the northern region is $1204 \pm 121 \mathrm{~mm}$, whereas for the southern region the corresponding values are $659 \pm 131 \mathrm{~mm}$. Furthermore, the total rainfall during the wettest year in the south is still substantially less than that during the driest year in the north. The higher totals and less variable rainfall in the north are mainly due to the influence of the ITCZ, which is located over northern Zambia in summer. In addition to the much greater interannual variability in the south, anomalously dry or wet years in the south only sometimes correspond to years with the same sign of rainfall anomaly in the north. Several cases of anomalously dry years in the south and anomalously wet years in the north exist (e.g. 1979/80, 1982/83) and vice versa. This result suggests that the 2 regions need to be considered sepa- rately and that different mechanisms apply in each case. In general, the rains in the south are often poorly distributed within the season. To examine this distribution in more detail, pentad CMAP and station data were used.

The mean DJF dry spell frequency during the period 1979-2001 is shown in Fig. 4 (CMAP and station data). Cressman interpolation (Cressman 1959) was used to plot the dry spell climatology derived from station data on the same $2.5 \times 2.5^{\circ}$ grid as the CMAP-derived values. Some differences exist between the 2 data sets, particularly for the grid boxes near the Congo and Tanzanian borders. Nevertheless, dry spell frequencies can be categorized into 2 regions across Zambia depending on their frequency. On average, the highest frequencies are observed over the southernmost part of the country, between latitudes 15 and $18^{\circ} \mathrm{S}$ whereas the northern part $\left(8\right.$ to $\left.15^{\circ} \mathrm{S}\right)$ has the least numbers of dry spells during the summer, consistent with the ITCZ being located over this region. The results over Zambia are consistent with those plotted over southern Africa as a whole by Usman \& Reason (2004). Re-examination of the results of Usman \& Reason (2004) suggests that, in terms of summer dry spell frequency, Zambia is located in a transition region between the low dry spell area of the Congo basin (which includes eastern Angola and northern Zambia) and the drought corridor defined by these authors as extending across southern Africa between 20 and $25^{\circ} \mathrm{S}$.

Fig. 5 shows the relationship between normalised DJF Niño 3.4 SST anomalies and dry spell frequency anomalies averaged over Zambia during the 1979/80 to 2001/02 (1979/80 to 1999/2000) periods derived from CMAP (station) data. A strong relationship between anomalies in dry spell frequency and Niño 3.4 SST is apparent for both rainfall data sets. Correlations between the dry spell and Niño 3.4 anomalies range from about 0.6 to 0.8 when calculated using a 10 yr running window (Fig. 6). The El Niño years of 1982/83, 1986/87, 1991/92, 1994/95 and 1997/98 all show increased dry spell frequency over Zambia, whereas the La Niña years of 1988/89, 1995/96, 1998/99 and 2000/01 all show decreased dry spell frequency. Years with anomalously large number of dry spells (>0.5 SD) are not only observed during all the El Niño years but also the non-El Niño seasons of 1979/80 and 1999/ 2000. The latter was a La Niña year when the main rainy belt shifted further south to lie over southern Mozambique and Zimbabwe (Reason \& Keibel 2004), and hence Zambia was drier than might have otherwise been expected. There is a general consistency 

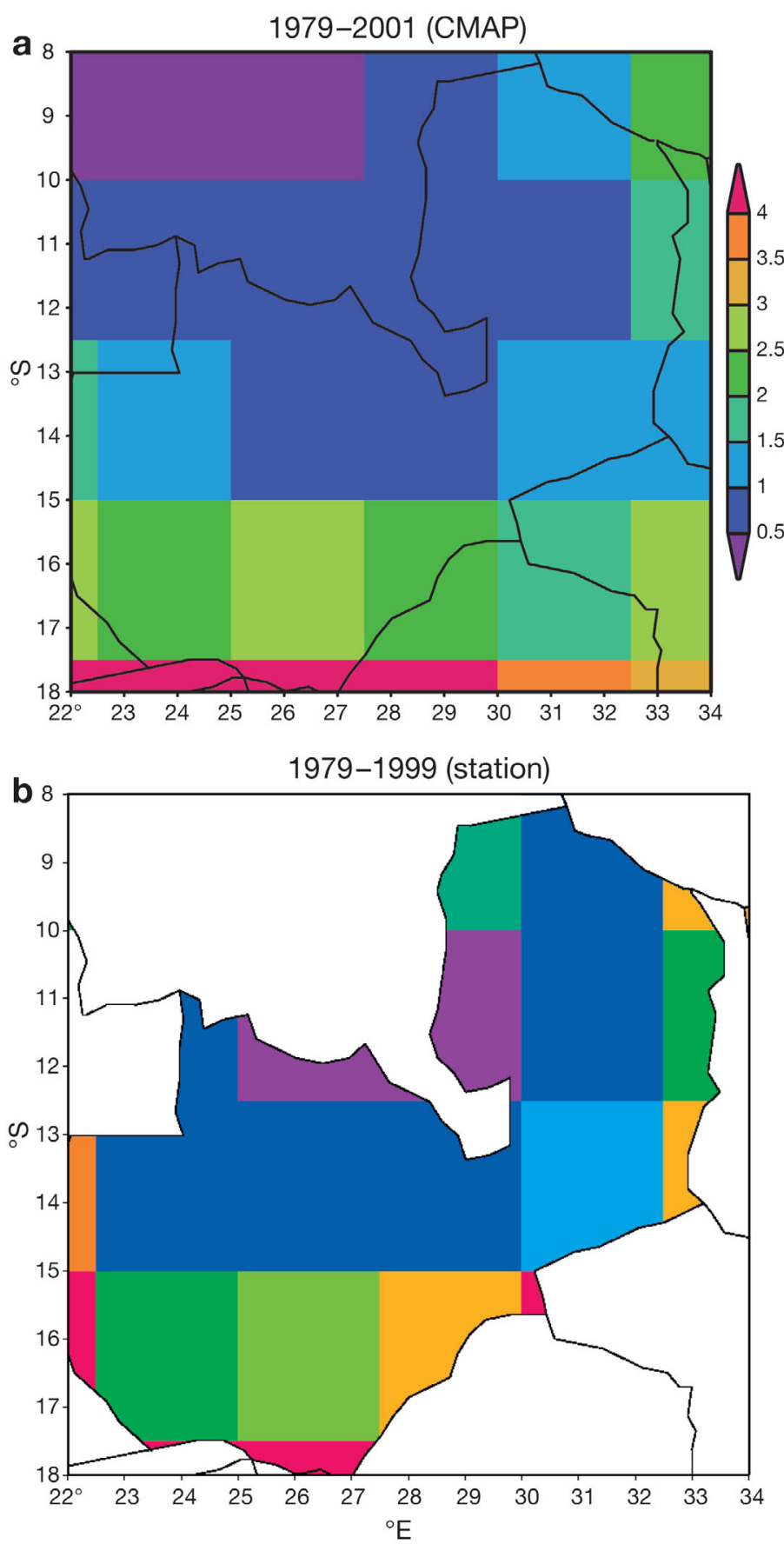

Fig. 4. Mean DJF dry spell frequency for Zambia, averaged over (a) 1979/80-2001/02 for CMAP (Climate Prediction Centre Merged Analysis of Precipitation) and (b) 1979/801999/2000 for station data

between anomalous dry spell years calculated from the 2 data sets, although the year with the largest number of dry spells in the CMAP time series corresponds to 1997/98, whereas from the station time series it is 1982/83. Although some differences exist between the CMAP- and station data-derived dry spell time series, the general relationship with Niño 3.4 is coherent and robust in both data sets. Note that the time axis is not the same, as the station data only extends to 1999/ 2000, whereas the CMAP data goes to 2001/02.

When the drier southern and wetter northern parts of the country are considered separately, there is a much stronger relationship with Niño 3.4 SST in both stationand CMAP-derived data for southern Zambia (correlation coefficients are 0.73 for both the station and CMAP, $p \leq 0.01$ ) (Fig. 7). This result suggests that the southern region is considerably more prone to ENSO impacts on rainfall. It is also located on the margins of the 'drought corridor' across southern Africa in the 20 to $25^{\circ} \mathrm{S}$ band, based on analysis of rainfall data across
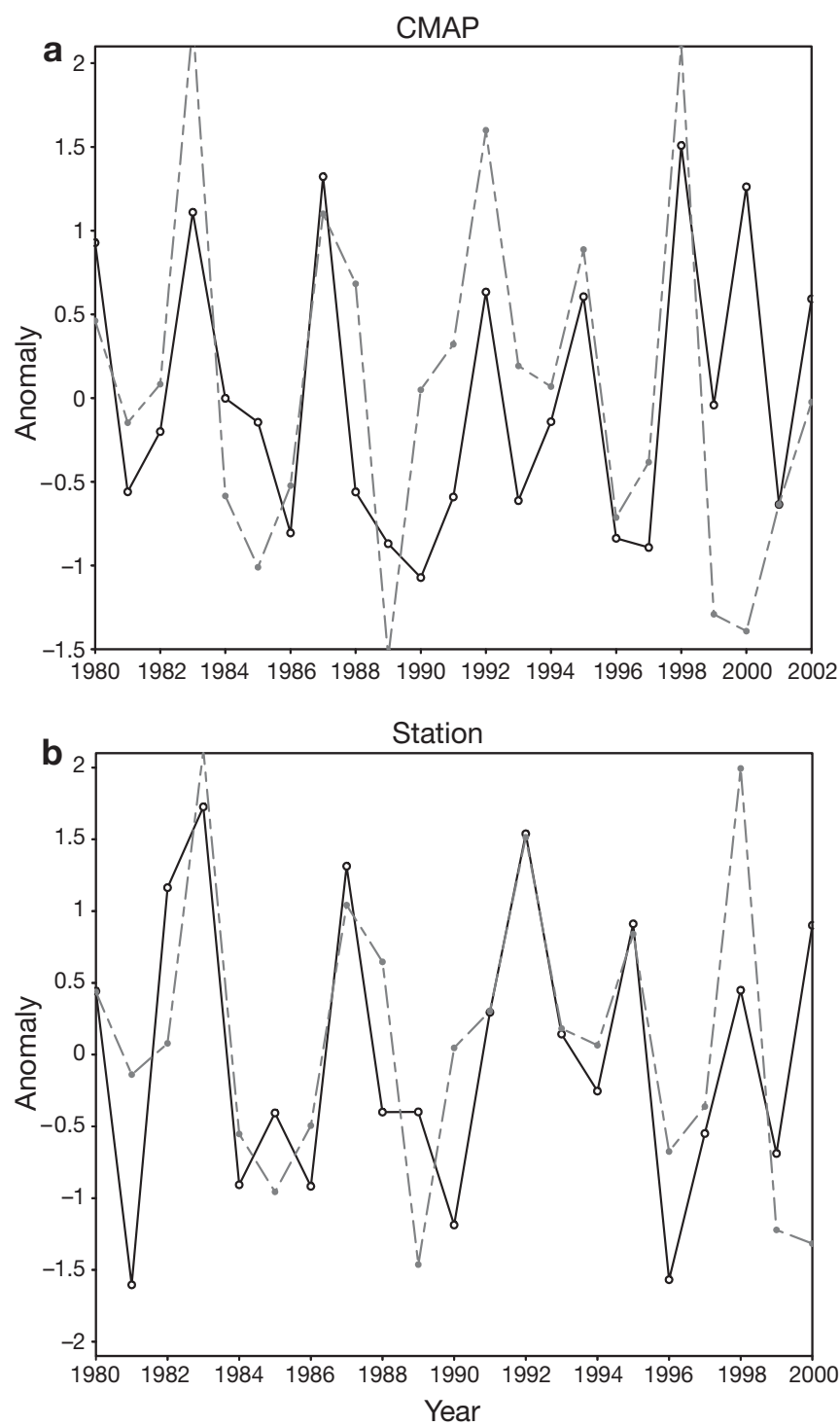

Fig. 5. Standardised DJF dry spell frequency anomalies over Zambia (continuous line) against Niño 3.4 SST anomaly time series (1979-2000) (dashed line) calculated for 1979/80-2001/02 using (a) CMAP data and (b) station data 


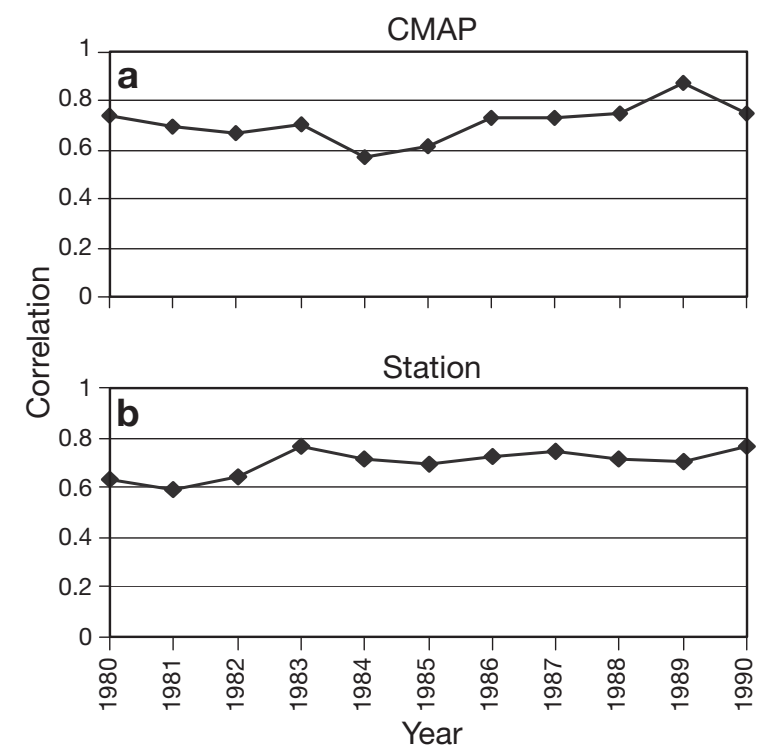

Fig. 6. Correlation between DJF dry spell frequency anomalies over Zambia and Niño 3.4 SST anomalies, calculated using a 10 yr running window and after both series were standardised. Dry spells were calculated from (a) CMAP data and (b) station data. Note: 1980 indicates correlation for 1980-1990, 1981 correlation for 1981-1991, etc.

Africa south of the equator (Usman \& Reason 2004). On the other hand, northern Zambia is located near the Congo rainforest and typically the ITCZ lies across the former in DJF. These factors, plus the fact that the high (low) pressure anomalies that establish themselves over southern Africa during El Niño (La Niña) years typically do not extend deep into the tropics (Lindesay 1988, Reason et al. 2000), may explain the reduced sensitivity to ENSO over the northern part of the country. Consistent with this proposition, the relationship between Niño 3.4 SSTs and dry spell frequency anomaly is far weaker for the northern region (Fig. 7a) (correlation coefficient 0.12).

Further support for the reduced impact of ENSO on the northern region can be seen in Table 1, which shows dry spell durations and dry spell frequencies during 5 El Niño seasons calculated from daily data for various stations across Zambia. Daily rainfall data were used in order to assess the duration of dry/wet spells. Computed across the country as a whole, each of the 5 El Niño seasons studied showed aboveaverage numbers of dry spells. Stations in the southern region (Livingstone and Choma) were most affected by El Niño, while those in the northern region (Isoka and Kasama) were least affected (Table 1). The impacts included an increase in dry spell frequency, and often in the duration of a given dry spell. In some cases, the duration of the longest dry spell was as much as 3 or 4 pentads. Stations in the western and eastern regions
Table 1. Number and duration of dry spells over various regions across Zambia. Mean no. of dry spells ( \pm SD) shown for each location. P: pentads

\begin{tabular}{|c|c|c|c|}
\hline \multirow{2}{*}{$\begin{array}{r}\text { Region } \\
\text { Year }\end{array}$} & \multirow{2}{*}{$\begin{array}{l}\text { No. of dry } \\
\text { spells (P) }\end{array}$} & \multicolumn{2}{|c|}{ Dry spell duratior } \\
\hline & & Mean & Max. \\
\hline \multicolumn{4}{|c|}{ Southern Region } \\
\hline \multicolumn{4}{|c|}{ Livingstone $(4 \pm 1.4)$} \\
\hline $1982-1983$ & 4 & 1.6 & 2 \\
\hline $1986-1987$ & 5 & 2.0 & 3 \\
\hline 1991-1992 & 4 & 2.3 & 2 \\
\hline $1994-1995$ & 5 & 1.9 & \\
\hline $1997-1998$ & 6 & 1.8 & 3 \\
\hline \multicolumn{4}{|c|}{ Choma $(3.2 \pm 1.5)$} \\
\hline $1982-1983$ & 3 & 1.9 & 3 \\
\hline $1986-1987$ & 4 & 2.5 & \\
\hline 1991-1992 & 5 & 2.7 & 4 \\
\hline $1994-1995$ & 6 & 1.3 & \\
\hline $1997-1998$ & 8 & 1.4 & \\
\hline
\end{tabular}

Eastern Region

Chipata $(2.3 \pm 1.1)$ 1982-1983

1986-1987

1991-1992

1994-1995

$1997-1998$

Lundazi $(2.5 \pm 2.5)$

1982-1983

1986-1987

$1991-1992$

1994-1995

1997-1998

Northern Region

Isoka $(1.0 \pm 0.9)$

1982-1983

1986-1987

1991-1992

1994-1995

1997-1998

Kasama $(0.7 \pm 1.0)$

1982-1983

1986-1987

1991-1992

1994-1995

1997-1998

\section{Western Region}

Kaoma (1.4 \pm 1.0$)$

1982-1983

1986-1987

1991-1992

1994-1995

1997-1998

Kabompo $(1.9 \pm 1.6)$

1982-1983

1986-1987

1991-1992

1994-1995

1997-1998

$\begin{array}{cc}1.7 & 2.1 \\ 1.1 & 1.1 \\ 2.4 & 3.2 \\ 1.6 & 3.3 \\ 1.3 & 1.6 \\ & \\ 1.2 & 3.5 \\ 3 & 2 \\ 1.2 & 1.6 \\ 1 & 1 \\ 1 & 1\end{array}$

$\begin{array}{cc}1.9 & 2.2 \\ 0 & 0 \\ 1.0 & 1.2 \\ 1.8 & 1.8 \\ 0 & 0 \\ & \\ 0 & 0 \\ 0 & 0 \\ 1 & 1 \\ 0 & 0 \\ 0 & 0\end{array}$

.2

2.8

3.0

0

6

8

.2

1

\begin{tabular}{lc}
1.1 & 1.2 \\
2.6 & 3.2 \\
1.2 & 1.2 \\
1.5 & 2.2 \\
1.8 & 2 \\
& \\
1.6 & 2.8 \\
1.4 & 1.4 \\
1.2 & 1.6 \\
1.5 & 1.4 \\
1.4 & 1.4 \\
\hline
\end{tabular}



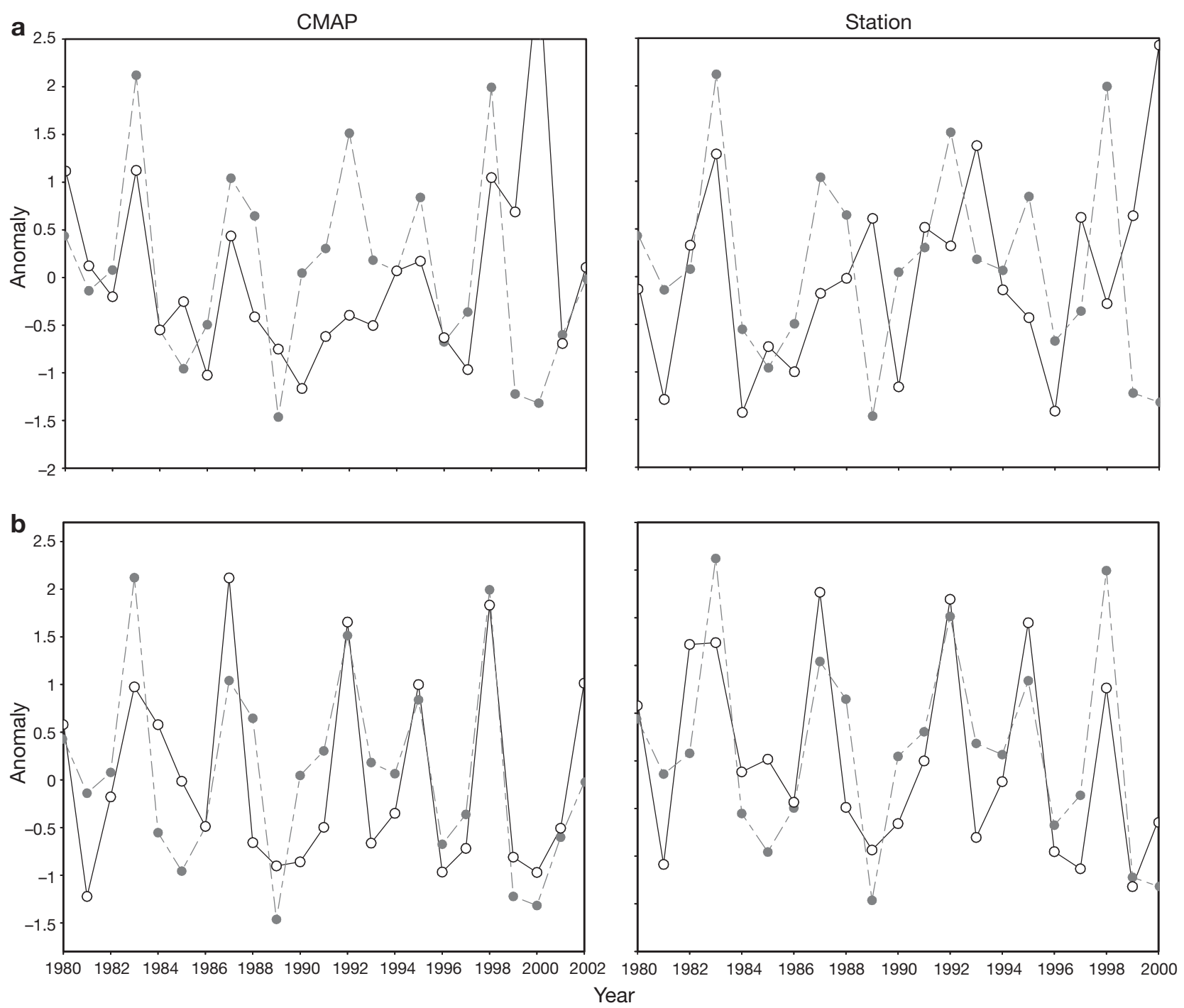

Fig. 7. Regional DJF dry spell frequency anomalies against standardised regional DJF Niño 3.4 SST anomalies (dashed) for (a) northern and (b) southern Zambia

tended to show increased dry spell frequencies in most El Niño years and sometimes a lengthening of dry spell duration to reach a maximum of about 3 pentads in a few cases. It is also clear from Table 1 that impacts of individual El Niño events differ across the regions, so that, with the exception of the southern stations, these events do not always have a robust and consistent countrywide effect on dry spell characteristics. To further illustrate the temporal distribution of rains during El Niño, Fig. 8 plots daily rainfall at a representative station in southern Zambia (Choma) and northern Zambia (Kasama) for 2 events. These events are chosen to indicate how southern Zambia, while almost always anomalously dry during El Niño events, can experience either relatively short and weak rainfall events that are well spread out in time (e.g. 1994/95) or a season with 1 very significant wet spell and some extensive dry periods (e.g. 1982/83). By contrast, at northern stations such as Kasama, the distribution of rainfall is much more even during El Niño events, although dry spells do occur during the season.

In addition to ENSO, modes of variability in the Indian Ocean such as the Indian Ocean Zonal Dipole Mode (ZDM; Saji et al. 1999, Webster et al. 1999) and the Subtropical South Indian Ocean Dipole SST pattern (Behera \& Yamagata 2001, Reason 2001, Hermes \& Reason 2005) may also be related to dry spell frequencies over Zambia. Comparison of the ZDM index of Saji et al. (1999) with the dry spell frequency time series reveals that the 2 series track together fairly closely for the southern Zambian case except during 1986/87 and 1998-2002 (not shown). By contrast, Fig. 7b indicates that the Niño 3.4 index tracks the dry spell index relatively well during this period. Although the ZDM index 

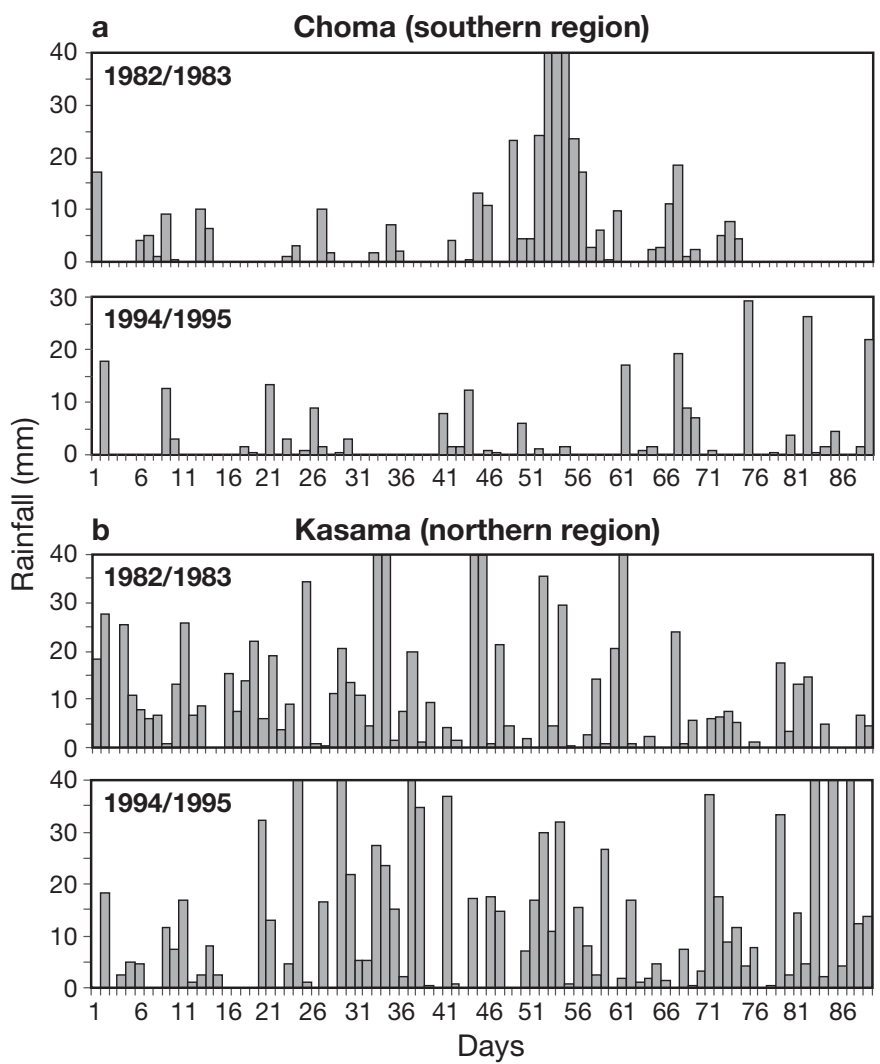

Fig. 8. Daily rainfall time series (DJF) for 2 El Niño events recorded at: (a) Choma (southern Zambia) and (b) Kasama (northern Zambia)

is closer to the 1983-1984 dry spell frequency index than is the Niño 3.4 index, the 1979-2002 correlation of the ZDM index with the dry spells $(0.61)$ is weaker than that found earlier for the Niño 3.4 index (0.73). Similarly weaker correlation coefficients for the ZDM index than for the Niño 3.4 index are found when monthly correlations lagged by 1 to 3 mo are calculated with the dry spell index. In addition, relationships between the dry spell index and the Subtropical South Indian Ocean Dipole SST pattern (calculated as in Hermes \& Reason 2005) during 1979-2002 were also investigated, but were found to be weaker $(\mathrm{r}=-0.48$ for $1979-2002)$ than those found between the dry spell index and either the ZDM or Niño 3.4 SST. In sum, it appears that the relationship between the dry spell frequencies and Niño 3.4 SST is stronger than that existing for the Indian Ocean SST modes.

\section{WET SPELL CHARACTERISTICS}

When calculated over the country as a whole, and using a criterion of $20 \mathrm{~mm}$ per pentad, the summers experiencing the largest number of wet spells were
1985/86, 1988/89, 1989/90, 1992/93, 1995/96, 1996/97 and 2000/01 (Fig. 9a). During these seasons, the highest number of wet spells tended to occur over the northwestern $\left(22\right.$ to $30^{\circ} \mathrm{E}, 8$ to $\left.15^{\circ} \mathrm{S}\right)$ and northeastern ( 30 to $34^{\circ} \mathrm{E}, 8$ to $15^{\circ} \mathrm{S}$ ) regions of the country.

Fig. $9 \mathrm{~b}$ suggests that an inverse relationship exists between normalised anomalies in the DJF frequency of wet spells averaged over Zambia and Niño 3.4 SST anomalies for 1979-2001 (correlation coefficient between the 2 series $=-0.50$ ). A reduced number of wet spells was observed during the 5 El Niño seasons whereas increased frequencies of wet spells occurred during the 1988/89, 1995/96 and 2000/01 La Niña seasons. However, the 1998/99 and 1999/2000 La Niña summers were characterised by average and belowaverage frequency of wet spells, respectively. In addi-
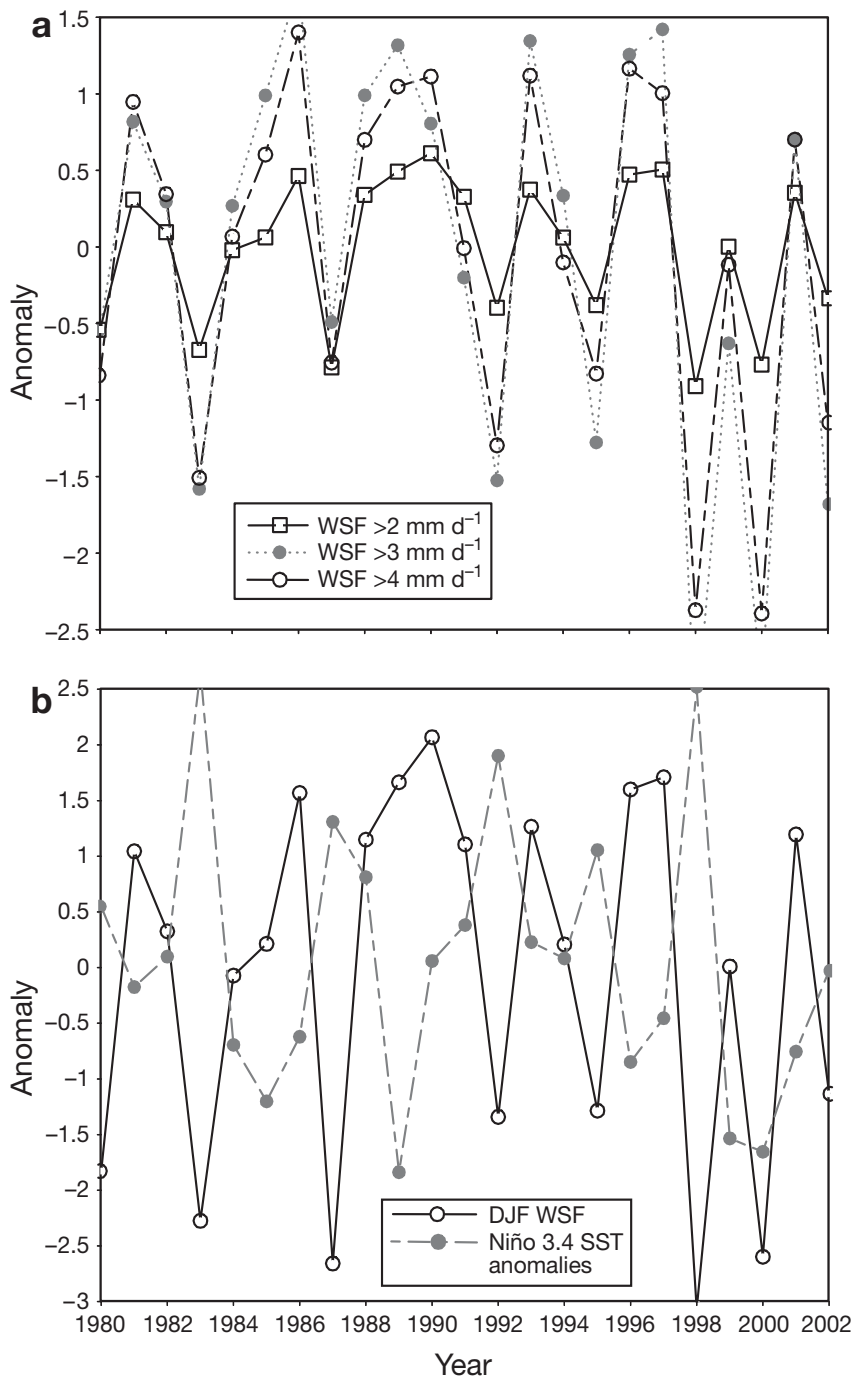

Fig. 9. Standardised DJF wet spell frequency anomalies (WSF) over Zambia, 1979/80-2001/02 (a) using the definition of wet spell as $>2,>3$ or $>4 \mathrm{~mm} \mathrm{~d}^{-1}$; (b) vs DJF Niño 3.4 SST anomalies 

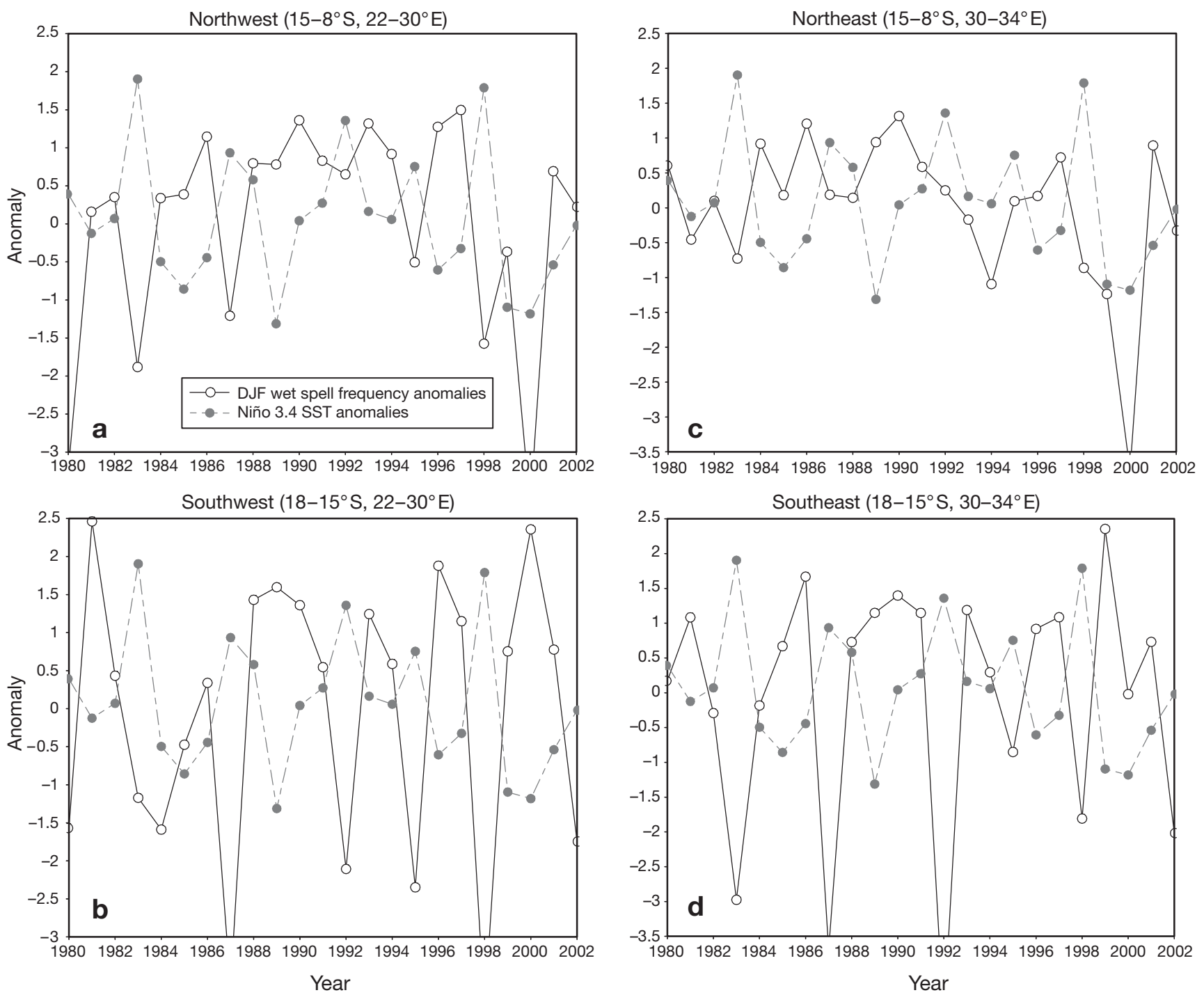

Fig. 10. Standardised DJF wet spell frequency anomalies vs DJF Niño 3.4 SST anomalies for Zambian regions

tion, not all seasons of above-average wet spell frequency are associated with La Niña events, suggesting that other factors may be important. Fig. 10 plots normalised anomalies in Niño 3.4 SST anomalies and DJF wet spells for 4 different areas of Zambia, to illustrate regional differences in this relationship. Similar to what was found for dry spell characteristics, a stronger relationship is observed for the southern regions (correlation coefficient with Niño 3.4 SST anomaly series = -0.66 [southwestern Zambia] and -0.71 [southeastern Zambia]) but less coherent signals are seen for the north. For the 2 northern regions, the Niño 3.4 series and rainfall series are sometimes in phase and sometimes out of phase (correlation coefficient $=-0.22$ [northwest] and 0.04 [northeast]).

To investigate potential mechanisms associated with the apparent ENSO relationships with dry and wet spell frequencies, the next section considers circulation anomalies derived for seasons with anomalously high numbers of dry/wet spells.

\section{CIRCULATION ANOMALIES DURING ANOMALOUS SEASONS}

\subsection{Dry spell circulation}

During DJF El Niño seasons with anomalously high dry spells, low-level moisture flux plots (Fig. 11) show southeasterly anomalies in the Mozambique Channel and a strong cyclonic (anticyclonic) anomaly over the subtropical S Indian (central tropical Indian) Ocean. A similar low level anomaly pattern was also found for El Niño years by Goddard \& Graham (1999). These pat- 

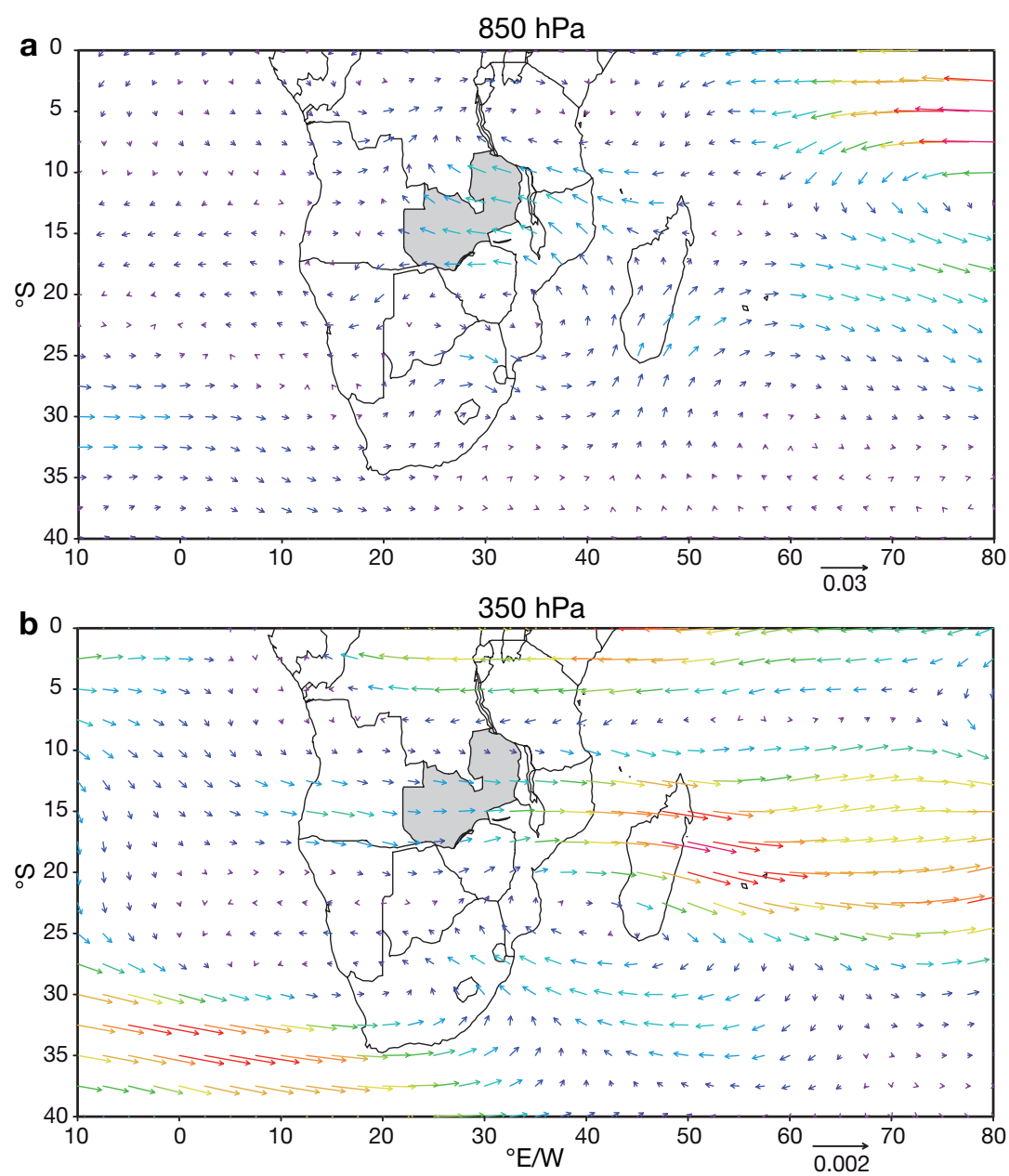

Fig. 11. Moisture flux $\left(\mathrm{kg} \mathrm{kg}^{-1} \mathrm{~m} \mathrm{~s}^{-1}\right)$ at 850 and $350 \mathrm{hPa}$ levels during years with anomalously high frequency of dry spells. Arrows below panels: scale vectors. Zambia shaded grey

terns reflect the high-pressure anomaly that extends from Australia during the El Niño mature phase (Kiladis \& Mo 1998, Reason et al. 2000) and suggest that the ascending branch of the Walker circulation is shifted offshore, consistent with the warm SST anomalies that develop in the tropical SW Indian Ocean (not shown). The velocity potential anomalies for DJF (Fig. 12) suggest that the main branch of the Walker circulation shifts eastward from northern Australia/ Indonesia into the central Pacific. In the African region, relative ascent is seen over the western Indian Ocean.

Easterly low level anomalies over Zambia (Fig. 11) imply reduced moisture penetration from the Angola Low and less low level moisture convergence over the country and hence increased dry spells. The upper level flow over tropical Africa is characterised by strong westerly anomalies from the South Atlantic Ocean and hence a weaker tropical easterly jet (Fig. 11). Positive geopotential height anomalies at $850 \mathrm{hPa}$ over the subcontinent (Fig. 13) imply relative subsidence and re- duced convection, consistent with the increase in dry spell frequency. Re-plotting Figs. 11-13 for the individual months (not shown) indicates that the anomalies in the region are stronger in December and February than in January.

The non-El Niño seasons with high dry spell frequency (1979/1980 and 1999/ 2000) are briefly considered separately. During 1979/80, the $850 \mathrm{hPa}$ geopotential height anomaly (Fig. 14a) shows strong anticyclonic conditions across tropical southern Africa with a low pressure anomaly just east of Madagascar. These patterns suggest that the Angola Low and terrestrial ITCZ were weaker, whereas the marine ITCZ in the tropical SW Indian Ocean was stronger, implying an offshore shift of the local Walker cell. Pressure tendency plots through the mid-levels (not shown) indicate that strongly subsiding conditions existed across tropical southern Africa from Angola to Madagascar with relative ascent over the central Indian Ocean. As a result, Zambia experienced increased dry spells during DJF 1979/1980 summer season. On the other hand, 1999/ 2000 shows an area of low pressure anomaly at $850 \mathrm{hPa}$ stretching across southern Africa from southern Angola to Zimbabwe and central Mozambique, whereas northern Zambia shows weakly positive height anomalies (Fig. 14b). Although this cyclonic anomaly might suggest reduced dry spells over Zambia, these did not occur. Most of the DJF seasonal anomaly was contributed to by a few strong tropical depressions (including Tropical Cyclone Eline) that tracked across Mozambique and Zimbabwe into southern Angola and northern Namibia, causing severe flooding in northern South Africa and southern Mozambique (Dyson \& Van Heerden 2001, Reason \& Keibel 2004). The outflow from these depressions led to relative subsidence over Zambia and an increase in dry spells. Plots of pressure tendency (not shown) indicate strong subsidence (ascent) at mid-levels over Zambia (Zimbabwe, Botswana and Namibia) during the period. Note that the cyclonic conditions were confined to January and February 2000 (not shown).

\subsection{Wet spell circulation}

The DJF composite moisture flux anomalies (Fig. 15) highlight the importance of the Angola Low and its 

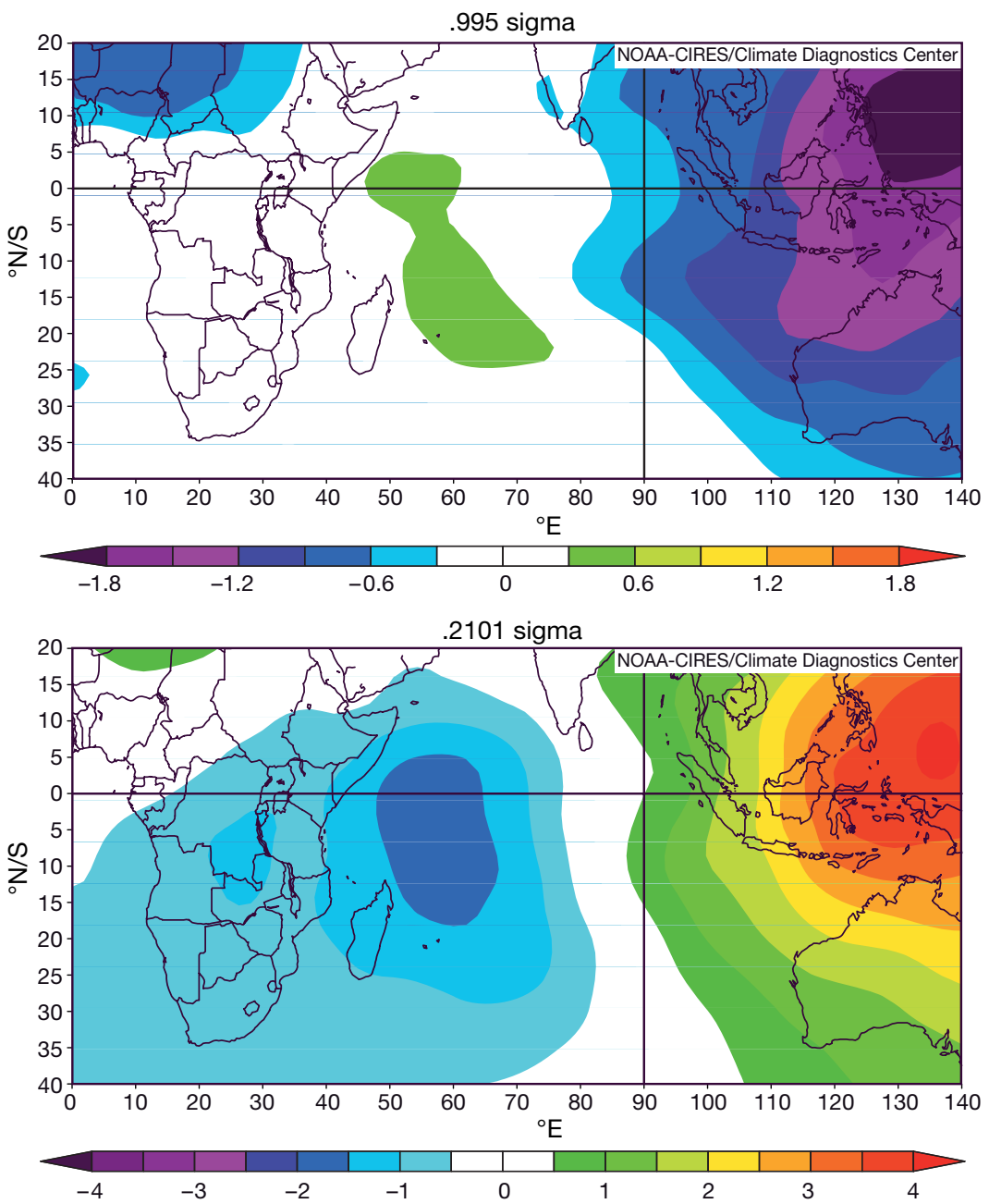

Fig. 12. Lower and upper level velocity potential $\left(10^{6} \mathrm{~m}^{2} \mathrm{~s}^{-1}\right)$ during years with anomalously high frequency of dry spells $(1983,1987,1992,1995,1998)$

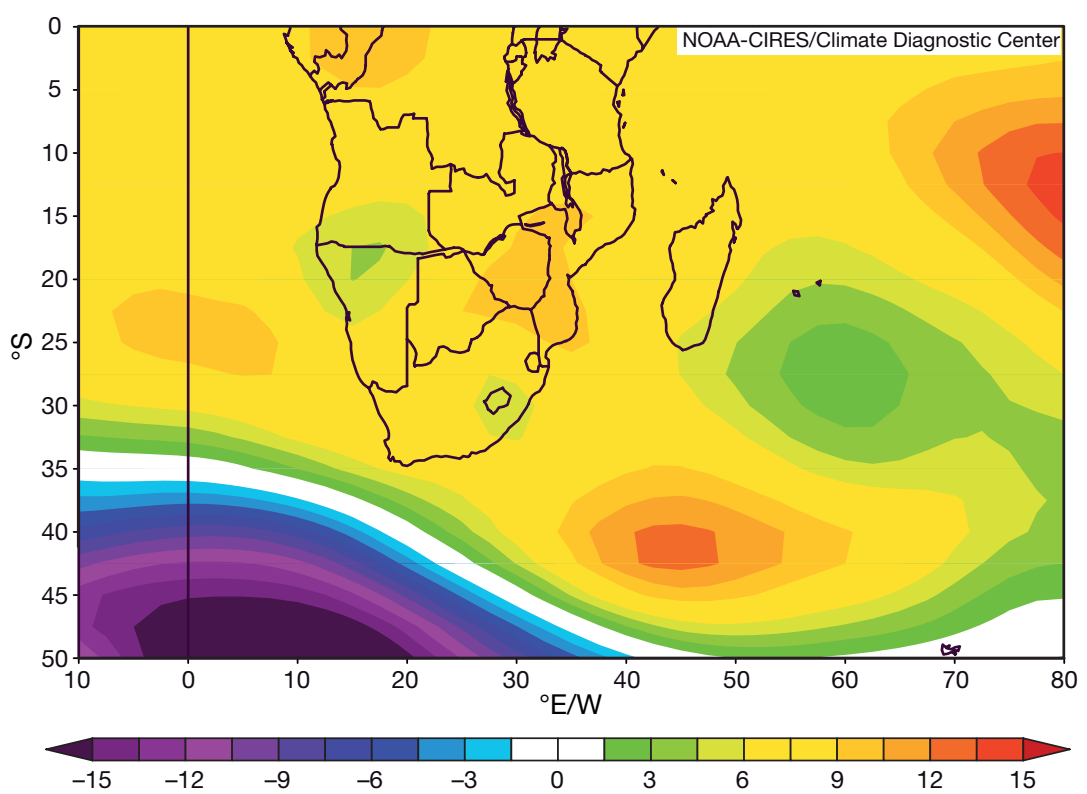

Fig. 13. DJF 850 hPa geopotential height composite anomalies (m) during years with anomalously high frequency of dry spells $(1983,1987,1992,1995,1998)$ linkage with the meridional arm of the ITCZ over Zambia for seasons with above average wet spells. In addition, positive SST anomalies (not shown) over parts of the tropical SE Atlantic are evident during this period, implying increased evaporation of moisture off this ocean region leading to more moisture import by the Angola Low. Strong westerly moisture flux anomalies are evident at $850 \mathrm{hPa}$ (Fig. 15a) thereby transporting moisture over Zambia. These westerly anomalies oppose the mean flow over eastern Zambia, Zimbabwe and Mozambique, implying low-level convergence, favourable for an increase in wet spells. Consistent with these factors, the low level divergence plot (Fig. 16a) shows an area of strong relative convergence across southern and central Zambia stretching west to an enhanced Angola Low and east to an enhanced ITCZ over northern Mozambique.

A region of strong ascent at mid-levels (Fig. 16b; note that negative values of the omega field imply relative ascent, and positive values a relative descent) is centred over southwestern Zambia and the Angola Low, and extends over most of Zambia, further reinforcing the conditions that favour increased frequencies of wet spells. These conditions of low level convergence and ascent through the lower and middle atmosphere are even stronger if the $3 \mathrm{La}$ Niña seasons are removed from the composite, indicating that this mode is not the principal cause of the observed patterns. At $350 \mathrm{hPa}$, the tropical easterly jet is weakened (Fig. 15) implying that rainfall-producing weather systems will tend to move less slowly than average through Zambia, consistent with increased numbers of wet spells. The velocity potential anomalies (Fig. 17) show substantially increased uplift at low levels over southern Africa, as well as upper level divergence, implying that the ascending limb of the local Walker circulation is over southern Africa, consistent with the high number of wet spells over Zambia. Over the tropical western Indian Ocean, an anticyclonic anomaly is present in the $850 \mathrm{hPa}$ moisture flux plot, leading to weaker low 

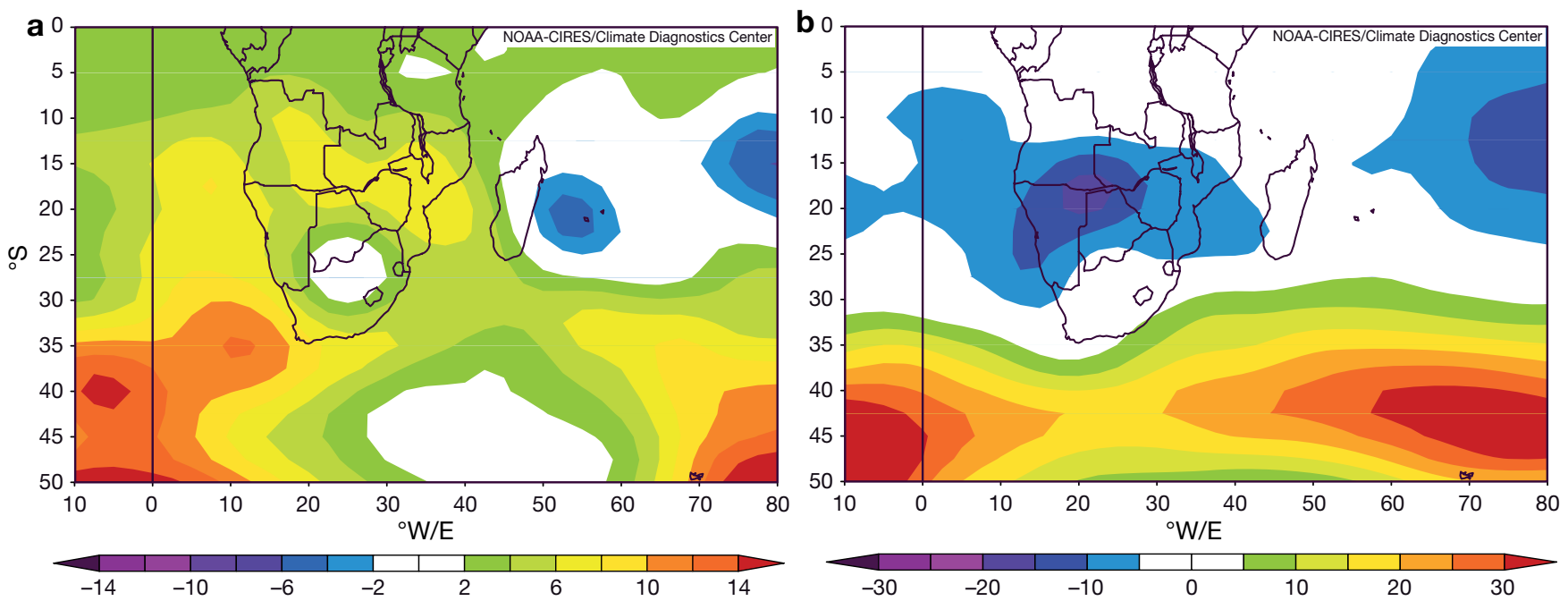

Fig. 14. DJF 850 hPa geopotential height anomalies (m) for non-El Niño seasons with anomalously high frequency in dry spell anomalies. (a) 1979/1980, (b) 1999/2000
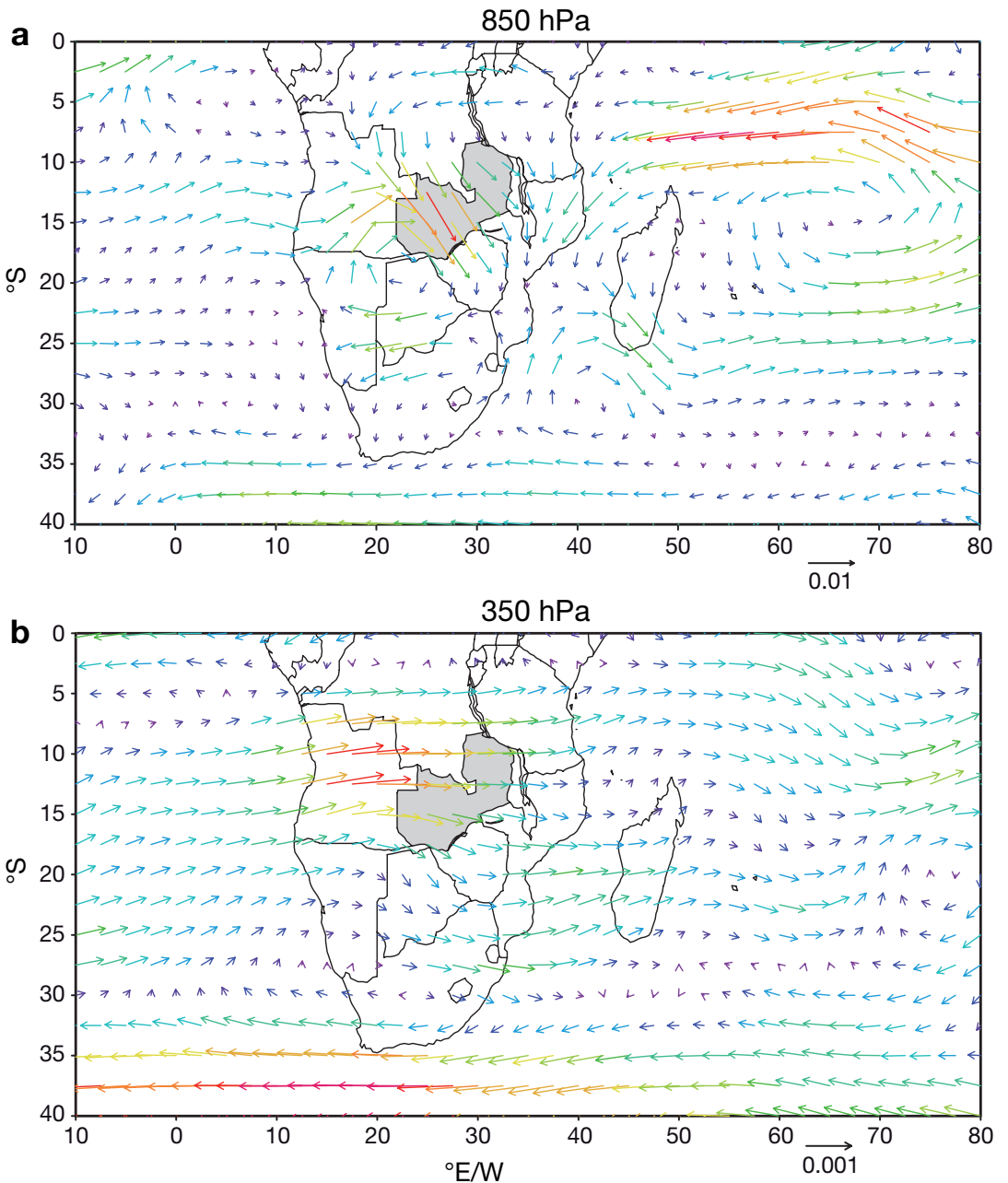

Fig. 15. Moisture flux anomalies $\left(\mathrm{kg} \mathrm{kg}^{-1} \mathrm{~m} \mathrm{~s}^{-1}\right)$ at (a) 850 and (b) $350 \mathrm{hPa}$ levels during years with anomalously high frequency of wet spells. Arrows below panel: scale vectors. Zambia shaded grey level monsoonal westerlies. As a result, less moisture from the NE monsoon is advected away from East Africa by these westerlies implying more low level moisture present over tropical southern Africa and favourable rainfall conditions.

\section{CONCLUSIONS}

Dry/wet spell characteristics for Zambia and their associated circulation anomalies were analysed. The southern part of Zambia is frequently subjected to seasons with increased dry spell frequency, whereas northern Zambia typically has relatively few dry spells during the austral summer (DJF) rainy season. This decrease in dry spells over the north is likely due to the position of the ITCZ, which is located over the area during the summer. An increase in dry spell frequency is observed over southern Zambia during all El Niño years, reflecting the influence of this climate mode on Zambia. However, not all seasons with anomalously high dry spell frequency correspond to El Niño. Although La Niña generally leads to favourable rainy conditions over Zambia, anomalously high dry spells over the country occurred during the 1999/2000 La Niña summer. In this particular case, it seemed that a few very strong tropical storms caused very wet 

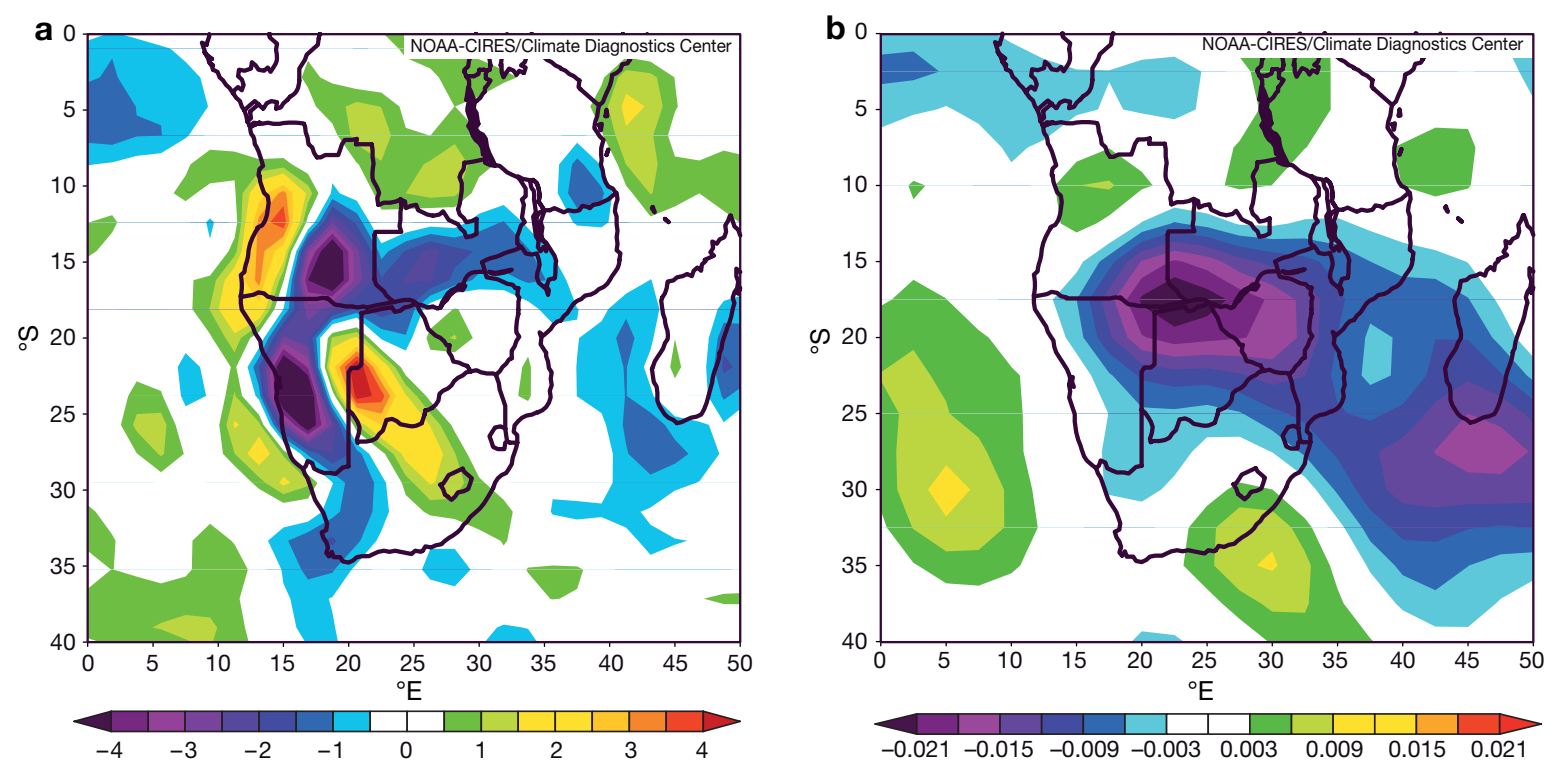

Fig. 16. (a) DJF low level divergence $\left(10^{-6} \mathrm{~s}^{-1}\right)$; (b) omega $\left(\mathrm{Pa} \mathrm{s}^{-1}\right)$ at the $500 \mathrm{hPa}$ level, during years with anomalously high frequencies of wet spells $(1986,1989,1990,1993,1996,1997,2001)$

conditions south of Zambia and the subsiding outflow from these led to increased dry spells over Zambia itself.

The northern region of the country typically experiences a large number of wet spells during the summer season. Seasons with above average number of wet spells tend to be those with an enhanced Angola Low importing more moisture off the tropical SE Atlantic Ocean into the region and low level westerly anomalies over Zambia. The importance of the latter feature is that it opposes the mean easterly flow over the southern part of the country, leading to low level convergence of moisture emanating from the SE Atlantic with that originating from the western Indian Ocean. In addition, there is often a link between this feature and the ITCZ, as well as a reduction in the export of moisture away from East Africa over the tropical Indian Ocean by weaker than average monsoonal westerlies during seasons with increased wet spell frequency. As a result, there is more low level moisture convergence over tropical southern Africa, and hence an increase in the number of wet spells. During seasons with more wet spells, the tropical easterly jet is weaker, suggesting that rain-producing systems will track more slowly across tropical southern Africa leading to more wet spells over Zambia.
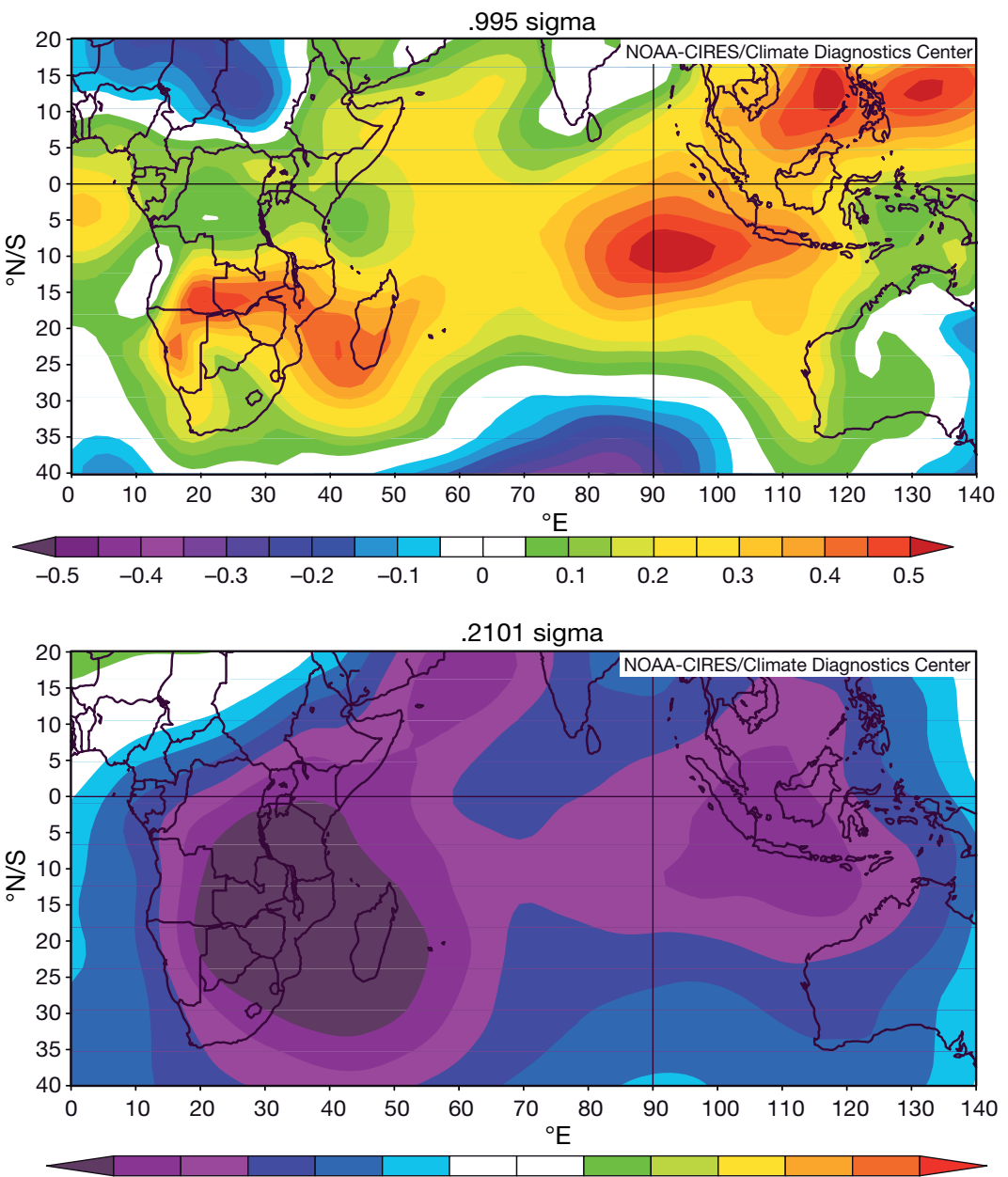

$-1.8$

$-1.2$

$-0.6$

1.8

Fig. 17. Lower and upper level velocity potential $\left(10^{6} \mathrm{~m}^{2} \mathrm{~s}^{-1}\right)$ during years with anomalously high frequency of wet spells $(1986,1989,1990,1993,1996,1997,2001)$ 
The frequencies of both dry and wet spells over Zambia during the main summer rainy season show a strong statistical relationship with the Niño 3.4 SST index, particularly for the southern part of the country. Relationships with Indian Ocean SST anomalies were also explored, but these were weaker than those found for Niño 3.4 SST. The physical relationship between Niño 3.4 SST and dry spell frequencies results from the Pacific SST anomalies generating regional atmospheric circulation anomalies over southern Africa, as summarised in the previous 2 paragraphs. Given that this relationship appears to exist, it may be possible to use the state of Niño 3.4 in the austral spring or even winter to predict behaviour of wet and dry spells during the summer rainy season across (at least) southern Zambia prior to the start of the rains. This possibility needs to be fully explored in future research, given the great importance of these fundamental aspects of Zambian climate for core user groups in agriculture, water resources, health, tourism and wildlife management.

Acknowledgements. This work arises from part of the first author's MSc thesis. Partial funding from the National Research Foundation is gratefully acknowledged. We thank M. Tadross for helpful discussions and D. Jagadheesha for programming assistance.

\section{LITERATURE CITED}

Allan RJ, Lindesay JA, Parker DE (1996) El Niño Southern Oscillation and climatic variability. CSIRO Press, Collingwood

Behera SK, Yamagata T (2001) Subtropical SST dipole events in the southern Indian Ocean. Geophys Res Lett 28: $327-330$

Cook C, Reason CJC, Hewitson H (2004) Wet and dry spells within particularly wet and dry summers in the South African summer rainfall region. Clim Res 26:17-31

Cressman GP (1959) An operational objective analysis system. Mon Weather Rev 87:367-374

Dyson LL, van Heerden J (2001) The heavy rainfall and floods over the northeastern interior of South Africa during February 2000. S Afr J Sci 97:80-86

Goddard L, Graham NE (1999) The importance of the Indian Ocean for simulating rainfall anomalies over eastern and southern Africa. J Geophys Res 104:19099-19116

Hermes JC, Reason CJC (2005) Ocean model diagnosis of interannual co-evolving SST variability in the South Indian and Atlantic Oceans. J Clim 18:2864-2882

Johnston PA, Archer ERM, Vogel CH, Bezuidenhout CN, Tennant WJ, Kuschke R (2004) Review of seasonal forecasting in South Africa: producer to end-user. Clim Res 28:67-82

Editorial responsibility: Madhar L. Khandekar, Unionville, Ontario, Canada
Kalnay E, Kanamitsu M, Kistler R, Collins W and 18 others (1996) The NCEP/NCAR 40-year reanalysis project. Bull Am Meteorol Soc 77:437-471

Kiladis GN, Mo KC (1998) Interannual and intraseasonal variability in the Southern Hemisphere. In: Karoly DJ, Vincent DG (eds) Meteorology of the Southern Hemisphere. Am Meteorol Soc Monogr, Boston, MA, p 307-336

Klopper E (1999) The use of seasonal forecasts in South Africa during the 1997/98 rainfall season. Water SA 25(3): 311-316

Lindesay JA (1988) South African rainfall, the Southern Oscillation and a Southern Hemisphere semi-annual cycle. J Clim 8:17-30

Matarira CH, Jury MR (1992) Contrasting meteorological structure of intra-seasonal wet and dry spells in Zimbabwe. Int J Climatol 12:165-176

Reason CJC (2001) Subtropical Indian Ocean SST dipole events and southern African rainfall. Geophys Res Lett 28: $225-228$

Reason CJC (2002) Sensitivity of the southern African circulation to dipole SST patterns in the South Indian Ocean. Int J Climatol 22:377-393

Reason CJC, Keibel A (2004) Tropical Cyclone Eline and its unusual penetration and impacts over southern Africa. Weather Forecast 19(5):789-805

Reason CJC, Allan RJ, Lindesay JA, Ansell TJ (2000) ENSO and climatic signals across the Indian Ocean basin in the global context. Part I. Interannual composite patterns. Int J Climatol 20:1285-1327

Reason CJC, Hachigonta S, Phaladi RF (2005) Interannual variability in rainy season characteristics over the Limpopo region of southern Africa. Int J Climatol 25(14): 1835-1853

Rouault M, Florenchie P, Fauchereau N, Reason CJC (2003) South East Atlantic warm events and southern African rainfall. Geophys Res Lett 30(5):8009, doi:10.1029/2002 GL014840

Saji NH, Goswami BN, Vinayachandran PN, Yamagata T (1999) A dipole mode in the tropical Indian Ocean. Nature 401:360-363

Stewart JI (1988) Response farming in rain-fed agriculture. The Wharf Foundation Press, Davis, CA

Tadross M, Hewitson BC, Usman MT (2005) The inter-annual variability of the onset of the growing season over southern Africa. J Clim 18(16):3356-3372

Usman MT, Reason CJC (2004) Dry spell frequencies and their variability over southern Africa. Clim Res 26:199-211

Vogel C, O'Brien K (2003) Climate forecasts in southern Africa. In: O'Brien K, Vogel C (eds) Coping with climate variability: the use of seasonal forecasts in southern Africa. Ashgate, Aldershot, p 75-96

Webster PJ, Loschnigg JP, Moore AM, Leben RR (1999) The great Indian Ocean warming of 1997-1998: evidence of coupled oceanic-atmospheric instabilities. Nature 401: $356-360$

Xie P, Arkin PA (1997) Global precipitation: a 17-year monthly analysis based on gauge observations, satellite estimates and numerical model outputs. Bull Am Meteorol Soc 78:2539-2558

Submitted: August 5, 2005; Accepted: March 11, 2006

Proofs received from author(s): July 24, 2006 